\title{
Particles Matters Accumulation and Anatomical Leaf Properties of Three Tree Species Growing in the Industrial Area in Jeddah, Saudi Arabia
}

\author{
Shaheen, A. M. , Al-Toukhy, A. A. and Hajar, A. S. \\ Biological Sciences Department, Faculty of Science, King Abdulaziz University, Saudi Arabia

\begin{abstract}
Particles matters accumulation and anatomical leaf properties of Camphor (Cinnamomum camphora), Henna (Lawsonia inermis), and Bougainvillea (Bougainvillea spectabilis) trees growing in the industrial zone in Jeddah - Saudi Arabia and Hada Al-Shame area (control) was done. The leaf properties of all tree species growing in the industrial and control showed that each stoma had a raised edge over the guard cell region. The guard cells appeared more shrunken on the polluted leaves as compared with unpolluted leave. The results indicated that the most deposition particles on leaf surfaces of all tree species were: soot (C) and soil dust with characteristic matrix elements ( $\mathrm{Si}, \mathrm{Al}, \mathrm{Mg}, \mathrm{Ca}, \mathrm{K}$ ); fuel oil particles rich in $\mathrm{Al}, \mathrm{Si}, \mathrm{Ca}$, and $\mathrm{Pb}$; coal ash particles containing $\mathrm{C}, \mathrm{Al}, \mathrm{Si}, \mathrm{K}, \mathrm{Ca}, \mathrm{S}$; and $\mathrm{Pb}$. As a result, leaves of those plant species may be used as bio-indicators for the assessment of particular matters in the industrial areas. Keywords: Particles matters; anatomical leaf properties; Air Pollution; Industrial areas.
\end{abstract}

\section{Introduction}

Plants can be used as a useful bio-indicators for the assessment of environmental pollution in the industrial areas (Tomasevic et al., 2004; Madejón et al., 2004, 2006; Gautam et al., 2005; Mingorance and Oliva, 2006). Several studies were carried out using plants as bioaccumulators or bio-indicators in environmental investigations (Celik et al., 2005; Aksoy and Demirezen, 2006; Yilmaz et al., 2006; Akguc et al., 2008; Maletsika and Nanos 2013; Saadullah, et al., 2014).

Particular matters in variety of forms such as dust particles, globules, aggregates etc., accumulate on leaf surfaces of industrial areas plants including higher plants. Keskin and Ili (2012) indicated that the chemical composition of particular matters on leaf surfaces of Pinus nigra Arn. subsp. pallasiana (Lamb.) Holmboe showed distinct differences between the regions.
The particulate matters have a negative mechanical effect where it covers the leaf blade reducing light penetration and blocking the opening of stomata. These impediments influence strongly the process of photosynthesis which rate declines sharply. Christodoulakis and Fasseas (1990) showed no significant changes in Laurus nobilis (a resistant xerophyitc plant) leaf structure exposed to air pollutants in Athens and under the action of pollutants, plants develop different morphological and anatomical changes.

Iqbal and Shafig (2001) indicated that the cement dust had a significant effect on the growth and structure of some plant species compared with non polluted plants, and toxic compounds such as fluoride, magnesium, lead, zinc, copper, sulphuric acid and hydrochloric acid found to be emitted by cement manufacturing factories. Farmer (1993) reported that cement dust pollutants block the stomata, reduction in number of annual crops. 
The high dust deposition on the leaf surface in urban and industrial area have been reported by Rao and Pal (1979) and Shetye and Chaphekar (1980). They concluded that high dust deposition on leaf surface at road side with heavy vehicular traffic may be due to spray of unborn oil residue of diesel or petrol on the leaf surface. According to Prajapati and Tripathi (2008) dust interception and its accumulation in different plant species not only depends upon the sources and amount of pollutants in the environment but also depends on morphological characters of plants like leaf size, texture, hair, length of petiole and weather condition and wind direction. Bhatnagar et al. (1985) reported that a very high dust fall on the leaves of all the nine plants under study growing in industrial in comparison to those growing in nonindustrial area. Lerman (1972) suggested that continuous application of cement dust clog the stomata, so interfering with gaseous exchange. Wang et al. (2015) reported that the rainfall caused a considerable increase in the accumulation of particles on the leaf surfaces at a high particular matters concentration, which resulted from the wet deposition of particular matters, and balanced the amount of particular matters on the leaf surfaces over a longer period.

The purpose of this study was to assesses the accumulation of particular matters on leaf surfaces and anatomical leaf properties of Camphor (Cinnamomum camphora), Henna (Lawsonia inermis), and Bougainvillea (Bougainvillea spectabilis) trees growing in the industrial zone in Jeddah - Saudi Arabia and Hada Al-Shame area.

\section{Materials and Methods}

\section{Study area}

This study was conducted at Jeddah city industrial area, which is situated between $21^{\circ} 24^{\prime} 37^{\prime \prime} \mathrm{N}$ latitude and $39^{\circ} 14^{\prime} 30^{\prime \prime} \mathrm{E}$ longitude and the control area (the Agricultural Research Station, Hada Al-Sham, King Abdulaziz
University at a distance of $120 \mathrm{~km}$ north-east of Jeddah) which situated between $21^{\circ} 47^{\prime} 50^{\prime \prime} \mathrm{N}$ latitude and $39^{\circ} 43^{\prime} 33^{\prime \prime} \mathrm{E}$ longitude in the West of Saudi Arabia.

\section{Plant Materials}

Three plant species with the same age, namely Bougainvillea (Bougainvillea spectabilis), Camphor (Cinnamomum camphora) and Henna (Lawsonia inermis) were selected for this study, as they were common in Jeddah industrial area (polluted) and the control area (unpolluted).

\section{Determinated characteristics}

Sampling time was done at the end of March, 2014 (this date is the end of the active working of the industrial factories in Jeddah). The particles matters accumulation and anatomical leaf properties of the 3 plant species were assessed in polluted and control.

The anatomical leaf properties study was done by using the Scanning Electron Microscopy. For Scanning Electron Microscopy (SEM) studies the samples (leaves) were cut as small pieces and placed on the double side carbon tape on aluminum stub and dried in air. All samples were sputtered with a $15 \mathrm{~nm}$ thick gold layer (JEOL JFC- 1600 Auto Fine Coater). The specimens were examined with a scanning electron microscope Quanta FEG 450, FEI, Amsterdam, Netherland. The microscope was operated at an accelerating voltage of $20 \mathrm{kV}$, according to (Dykstra, 1993 and Hayat, 2000). Then, the samples were photographed by the SEM.

The analyses of presence atmospheric particles on leaf surfaces were carried out by FESEM method, observing the presence and shape of the particles, followed by EDS analyses to determine elemental composition of the particles on leaf surfaces, as described by Tomasevic, et al. (2004).

\section{Experimental Design}

A completely randomized design with 4 replications were used to study each plant 
species separately where the industrial zone of Jeddah (polluted area) and the Hada Al-Shame (control area) were the treatments.

\section{Results and Discussion}

\section{Anatomical leaf properties}

Based on the leaf characteristics, the three different plants species were recorded as fallow:

\section{Camphor}

Anatomical leaf properties of Camphor trees growing in the industrial (polluted) and control (unpolluted) areas showed stomata with normal structure (Fig. 1a, b). Each stoma had a raised edge over the guard cell region, which is typical for plant (Carpenter, 2005). The guard cells appeared more shrunken on the polluted leaves as compared with unpolluted leaves (Fig. 1a, b).

The study showed that the stomata of Camphor plant leaves growing in the control area (unpolluted) were not plugged by particulates as compared with the plants growing in the industrial area (polluted) (Fig. 1c, d). Although the particles were present on the leaf surface of the plants growing in the industrial are. At industrial area the particles were abundant and clumped together, whereas they were less frequent and more scattered on leaves from the control area (unpolluted) (Fig. 1c, d).

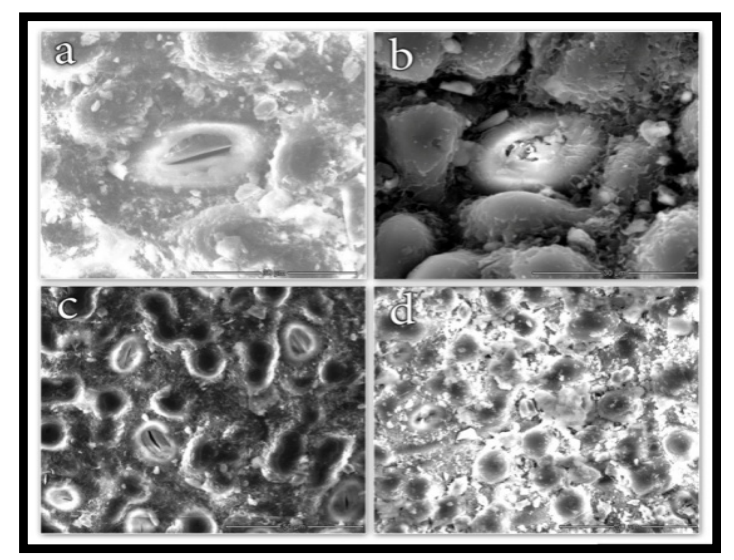

Fig. (1). Anatomical leaf properties of Camphor trees from an industrial (polluted) and control (unpolluted) areas (a) unpolluted showing stomata with normal structure; (b), polluted showing the damage in the stomata structure; (c), unpolluted showing leaf surface with normal sunken shape of the stomata; (d), polluted showing the complete blockage of stomata with pollutants.

\section{Henna}

The Anatomical leaf properties of Henna trees growing in the industrial (polluted) and control (unpolluted) areas (Fig. 2a, b) showed that each stoma had a raised edge over the guard cell region, which is typical for plant (Carpenter, 2005). The guard cells appeared more shrunken on the polluted leaves as compared with unpolluted leaves (Fig. 2 a, b).

The study showed that the stomata of Henna plant leaves growing in the control area (unpolluted) were not plugged by particulates as compared with the plants growing in the industrial area (polluted) (Fig. 2 c, d). Although the particles were present on the leaf surface of the plants growing in the industrial area. At industrial area the particles were abundant and clumped together, whereas they were less frequent and more scattered on leaves from the control area (unpolluted) (Fig. 2 c, d).

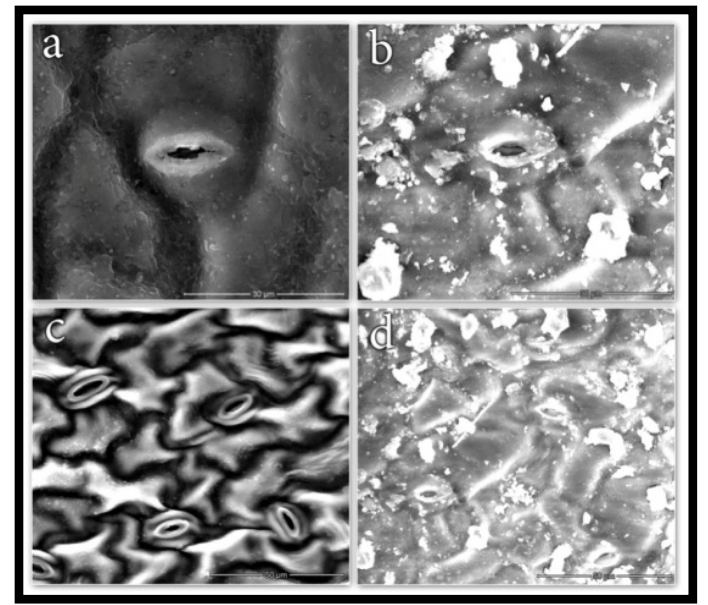

Fig. (2). Anatomical leaf properties of Henna trees from an industrial (polluted) and control (unpolluted) areas (a) unpolluted showing stomata with normal structure; (b), polluted showing the damage in the stomata structure; (c), unpolluted showing leaf surface with normal sunken shape of the stomata; (d), polluted showing the complete blockage of stomata with pollutants. 


\section{Bougainvillea}

The leaf properties of Bougainvillea trees growing in the industrial (polluted) and control (unpolluted) areas (Fig. 3a, b) showed that each stoma had a raised edge over the guard cell region, which is typical for plant (Carpenter, 2005). The guard cells appeared more shrunken on the polluted leaves as compared with unpolluted leaves (Fig. 3a, b).

The study showed that the stomata of Bougainvillea plant leaves growing in the control area (unpolluted) were not plugged by particulates as compared with the plants growing in the industrial area (polluted) (Fig. 3c, d). Although the particles were present on the leaf surface of the plants growing in the industrial are. At industrial area the particles were abundant and clumped together, whereas they were less frequent and more scattered on leaves from the control area (unpolluted) (Fig. 3c, d).

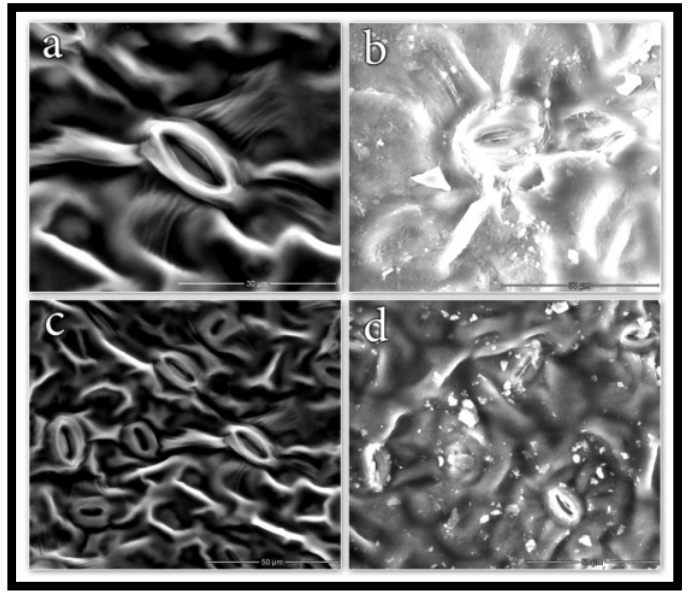

Fig. (3). Anatomical leaf properties of Bougainvillea trees from an industrial (polluted) and control (unpolluted) areas (a) unpolluted showing stomata with normal structure ; (b), polluted showing the damage in the stomata structure; (c), unpolluted showing leaf surface with normal sunken shape of the stomata; (d), polluted showing the complete blockage of stomata with pollutants.

The above results for all tree species are in agreement with those of Pal et al. (2002) that showed leaf stomata of trees growing at sites of high pollution load appeared to have smaller size, reduced aperture size, and destructed guard cells. Modification of the frequency and sizes of stomata as a response to the environmental stress is an important manner of controlling the absorption of pollutants by plants (Gostin, 2009). Also, Gostin (2009) reported the decrease in stomatal size in Lotus corniculatus, Trifolium montanum, T.pratense, and T.repens. Saquib et al. (2010) reported that the air pollution stress around the thermal power plant lead to the significant reduction in stomatal conductance. The results obtained by Youssef, et al., (2013) reported that the trees of Ligustrum japonicum and Olea europea (Oleaceae) growing under industrial areas showed stomata closed completely with pollutants particles and consequently expected to affect the physiological operations inside the plant cell. Iqbal, et al. (1996) reported that the smaller size of stomata and the decrease in stomata aperture may operate as a defense mechanism against inhibitory action of pollutants on photosynthesis.

\section{Morphological characters of the particles matters}

The results of morphology and chemical composition of the particles deposited on leaf surfaces of the three different plant species growing in the industrial (polluted) and control (unpolluted) areas were recorded in the present study.

\section{Camphor}

The morphological characters of the particles obtained from the scanning electron microscopy from the industrial (polluted) leaf surfaces of Camphor showed that the particles were in different sizes and shape, which strongly covered the leaves. Also, the particles on the leaves from control (unpolluted) were in different sizes and shape, but distributed in small area (Fig.4a \& c).

The scanning electron microscopy micrographs and corresponding EDS spectrums and chemical composition of leaves of Camphor 
from the industrial (polluted) and control (unpolluted) areas are shown in Table 30 and Fig. $4 \mathrm{~b} \& \mathrm{~d}$, respectively. The chemical composition of the particles deposited on leaves of this species indicated that the most abundant particles were: soot (C) and soil dust with characteristic matrix elements $(\mathrm{Si}, \mathrm{Al}$, $\mathrm{Mg}, \mathrm{Ca}, \mathrm{K}, \mathrm{Na}$ ); fuel oil particles rich in $\mathrm{Al}$, $\mathrm{Si}, \mathrm{Ca}$, and $\mathrm{Pb}$; coal ash particles containing $\mathrm{C}$, $\mathrm{Al}, \mathrm{Si}, \mathrm{K}, \mathrm{Ca}$; and produced from the local industrial processes.

The concentrations of $\mathrm{C}$ content decreased on the leaves collected from control area as compared with industrial area. The concentration of $\mathrm{O}, \mathrm{Mg}, \mathrm{Al}, \mathrm{Si}$, and $\mathrm{Ca}$ increased on the leaves collected from polluted area as compared with unpolluted area. The $\mathrm{Na}, \mathrm{Pb}$ and $\mathrm{K}$ were found only on the surface of leaves collected from polluted area (Table 29).

The particles morphology and chemical composition on the leaves of Camphor indicated by the SEM-EDAX procedure, it may be suggested that particles deposited on the leaves mostly originated from the traffic within the industrial zone and local industries.

Table (30). FESEM-EDS analytical data (average wt. \%) on particles constituting on leaves of Camphor trees growing in the industrial (polluted) and control (unpolluted) areas.

\begin{tabular}{|c|c|c|c|c|c|c|c|c|c|}
\hline \multirow{2}{*}{ Location } & \multicolumn{7}{|c|}{ Elemental percentage (\%) } \\
\cline { 2 - 10 } & $\mathbf{C}$ & $\mathbf{O}$ & $\mathbf{N a}$ & $\mathbf{M g}$ & $\mathbf{A l}$ & $\mathbf{S i}$ & $\mathbf{P b}$ & $\mathbf{K}$ & $\mathbf{C a}$ \\
\hline $\begin{array}{c}\text { Control } \\
\text { (unpolluted) }\end{array}$ & 40.09 & 20.57 & -- & 00.38 & 01.04 & 02.09 & --- & --- & 00.74 \\
\hline $\begin{array}{c}\text { Industrial } \\
\text { area } \\
\text { (polluted) }\end{array}$ & 75.18 & 33.60 & 00.78 & 01.09 & 04.06 & 08.75 & 07.56 & 00.55 & 03.51 \\
\hline
\end{tabular}

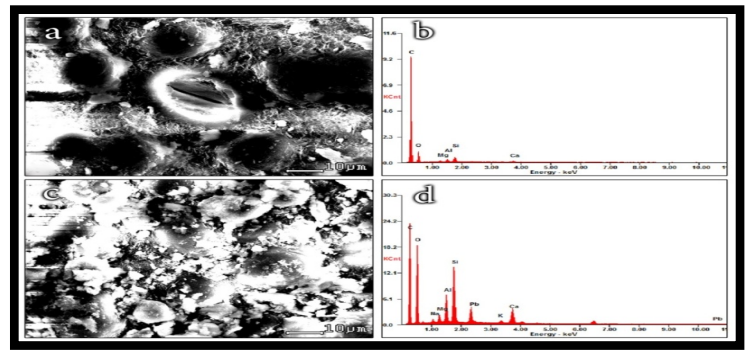

Fig. (4). Scanning electron micrographs and EDS spectrums of particulate matters on the leaves of
Camphor trees growing in the control area $(a, b)$ and in the industrial area $(c, d)$.

\section{Henna}

The morphological characters of the particles matters obtained from the scanning electron microscopy from the industrial (polluted) leaf surfaces of Henna showed that the particles were in different sizes and shape on both leaves collected from control (unpolluted) and polluted areas and distributed in small area (Fig.5a and c).

The scanning electron microscopy micrographs and corresponding EDS spectrums and chemical composition of leaves of Henna from the industrial (polluted) and control (unpolluted) areas are shown in Table 31 and Fig.5b \& d, respectively. The chemical composition of the particles deposited on leaves of this species indicated that the most abundant particles were: soot (C) and soil dust with characteristic matrix elements $(\mathrm{Si}, \mathrm{Al}$, $\mathrm{Mg}, \mathrm{Ca}, \mathrm{K}, \mathrm{Na}$ ); fuel oil particles rich in $\mathrm{Al}$, $\mathrm{Si}, \mathrm{Ca}$, and $\mathrm{Pb}$; coal ash particles containing $\mathrm{C}$, $\mathrm{Al}, \mathrm{Si}, \mathrm{K}, \mathrm{Ca}, \mathrm{S}$; and $\mathrm{Pb}$. The concentrations of $\mathrm{C}$ content not significantly different between polluted or the control areas. Under the control area the concentrations of $\mathrm{O}, \mathrm{Al}, \mathrm{Si}$ and $\mathrm{S}$ were significantly higher than in the industrial zone. These results might be due to the effect of the fuel (gasoline) used in the agricultural machines in the Agricultural Research Station and the wind strength and directions especially for the $\mathrm{Si}$ concentrations (Dmuchowski and Bytnerowicz, 2009). The other particles of $\mathrm{Na}$, $\mathrm{Mg}, \mathrm{Pb}, \mathrm{Cl}, \mathrm{K}$ and $\mathrm{Ca}$ were significantly higher in the tree leaves in the industrial zone from the control area due to the industrial emissions pollutants.

The present particles on the Henna leave might been due to the pollutants produced from the industries and the near traffic. 
Table 31. FESEM-EDS analytical data (average wt. \%) on particles constituting on leaves of Henna trees growing in the industrial (polluted) and control (unpolluted) areas.

\begin{tabular}{|c|c|c|c|c|c|c|c|c|c|c|c|}
\hline Locatio & & & & Elen & nental & I perce & entage & $(\%)$ & & & \\
\hline $\mathrm{n}$ & C & $\bar{O}$ & $\mathrm{Na}$ & $\mathrm{Mg}$ & $\mathbf{A l}$ & $\mathrm{Si}$ & $\bar{S}$ & $\mathbf{P b}$ & $\mathrm{Cl}$ & $\mathbf{K}$ & $\mathrm{Ca}$ \\
\hline $\begin{array}{l}\bar{\Xi} \\
\bar{\Xi} \\
\tilde{E}\end{array}$ & 53.91 & 39.41 & -- & 00.38 & 00.90 & 00.53 & 00.33 & --- & -- & --- & 01.44 \\
\hline 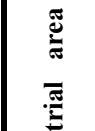 & 57.01 & 29.58 & 04.30 & 00.92 & 00.39 & 00.33 & --- & 04.85 & 4.20 & 01.51 & 03.51 \\
\hline$\stackrel{\mathscr{E}}{\underline{\Xi}}$ & & & & & & & & & & & \\
\hline
\end{tabular}

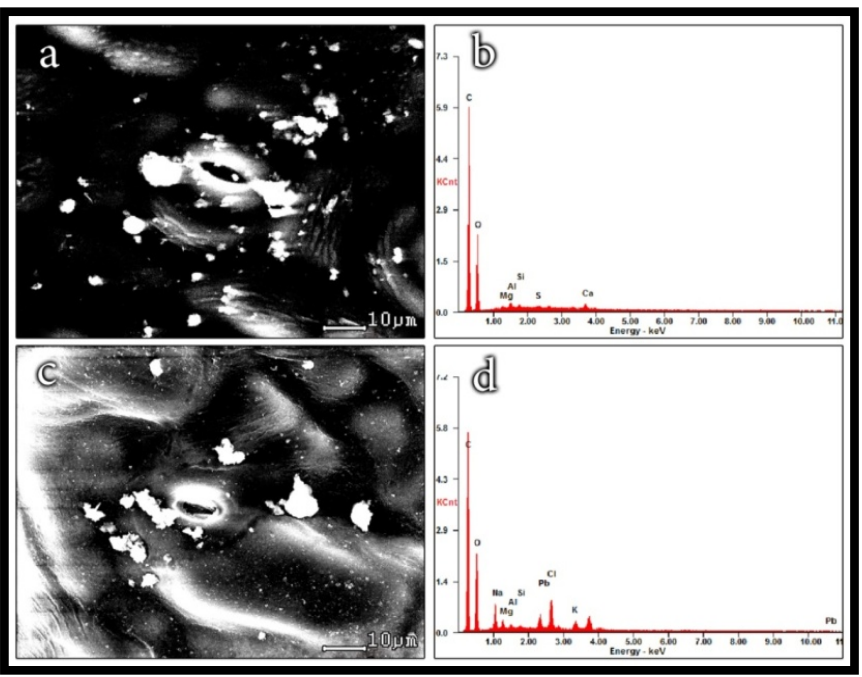

Fig. (5). Scanning electron micrographs and EDS spectrums of particulate matters on the leaves of Henna trees growing in the control area $(a, b)$ and industrial area $(c, d)$.

\section{Bougainvillea}

The morphological characters of the particular matters obtained from the scanning electron microscopy from the industrial (polluted) leaf surfaces of Bougainvillea showed that the particles were in different sizes and shape on both leaves collected from control (unpolluted) and polluted areas and distributed in small area (Fig.6a \& c).

The scanning electron microscopy micrographs and corresponding EDS spectrums and chemical composition of leaves of Bougainvillea from the industrial (polluted) and control (unpolluted) areas are shown in
Table 32 and Fig.6b \& d, respectively. The chemical composition of the particles deposited on leaves of this species indicated that the most abundant particles were: soot (C) and soil dust with characteristic matrix elements ( $\mathrm{Si}, \mathrm{Al}, \mathrm{Mg}, \mathrm{Ca}, \mathrm{K}$ ); fuel oil particles rich in $\mathrm{Al}, \mathrm{Si}, \mathrm{Ca}$, and $\mathrm{Pb}$; coal ash particles containing $\mathrm{C}, \mathrm{Al}, \mathrm{Si}, \mathrm{K}, \mathrm{Ca}, \mathrm{S}$; and $\mathrm{Pb}$. The obtained results showed no significant differences between the concentrations of $\mathrm{C}$, $\mathrm{O}, \mathrm{Mg}$ and $\mathrm{Ca}$ on the leaves of the trees grown in the control or the industrial areas, while the concentrations of $\mathrm{Al}, \mathrm{Si}, \mathrm{S}, \mathrm{P}$ and $\mathrm{Pb}$ were significantly higher under the industrial zone than the control area, but $\mathrm{S}, \mathrm{Cl}$ and $\mathrm{K}$ were higher in the control area than the industrial zone with significantly values (Table 30). These results reflected the industrial emissions effects and the used fuel in Hada Al-Sham area effects besides the genotype $\times$ environment interaction.

The high accumulated polluted particles on the Bougainvillea leaves might bean due to the industrial and traffic emissions in the industrial zone and the machine fuel emissions and chemical fertilizers and chemical pesticides used in the Agricultural Research Station in Hada Al-Sham.

Table (32). FESEM-EDS analytical data (average wt. \%) on particles constituting on leaves of Bougainvillea trees growing in the industrial (polluted) and control (unpolluted) areas.

\begin{tabular}{|c|c|c|c|c|c|c|c|c|c|c|c|}
\hline & \multicolumn{11}{|c|}{ Elemental percentage $(\%)$} \\
\hline & $\overline{\mathbf{C}}$ & 0 & Mg & Al & $\mathrm{Si}$ & $\mathrm{s}$ & $\bar{P}$ & $\mathbf{P b}$ & $\mathrm{Cl}$ & $\overline{\mathbf{K}}$ & $\mathrm{Ca}$ \\
\hline $\begin{array}{l}\bar{\Xi} \\
\bar{\Xi} \\
\dot{\Xi}\end{array}$ & 58.42 & 26.47 & 01.21 & 00.57 & 01.06 & 00.38 & -- & --- & 04.21 & 06.83 & 00.84 \\
\hline 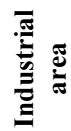 & 62.83 & 23.35 & 01.38 & 00.84 & 01.55 & -- & 00.28 & 01.41 & 02.74 & 04.55 & 01.07 \\
\hline
\end{tabular}




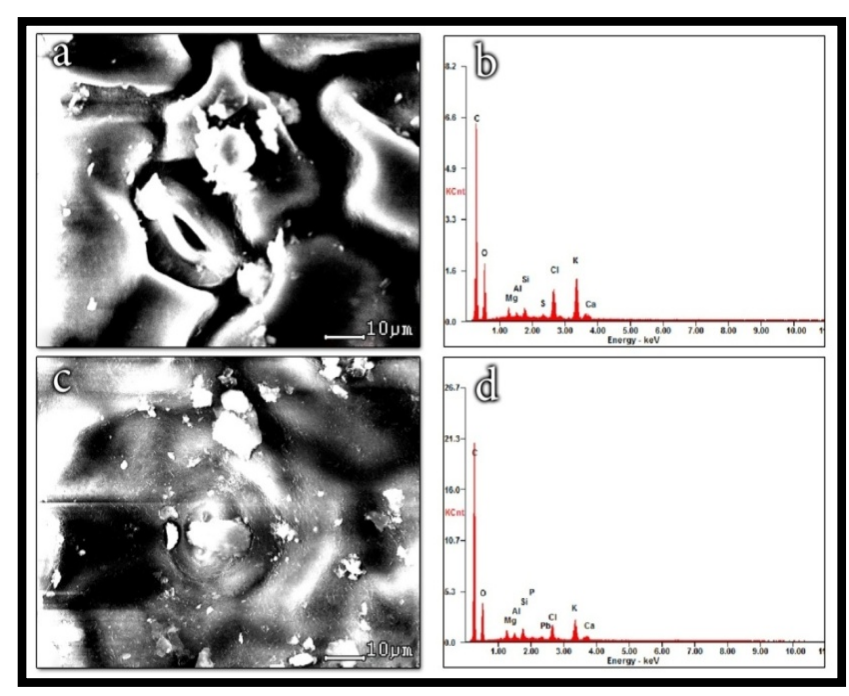

Fig. (6). Scanning electron micrographs and EDS spectrums of particulate matters on the leaves of Bougainvillea trees growing in the control area $(a, b)$ and industrial area $(c, d)$.

Tomašević and Aničić, (2010) Using a scanning SEM-EDAX, studded the morphological and chemical composition of deposited particles on urban tree leaves of common deciduous trees: Aesculus hippocastanum and Tilia spp. and indicated that the most abundant particles were soot and dust with minor constituents such as $\mathrm{Pb}, \mathrm{Zn}$, $\mathrm{Ni}, \mathrm{V}, \mathrm{Cd}, \mathrm{Ti}, \mathrm{As}$, and $\mathrm{Cu}$. The effect of particles matter accumulation on vegetation depends on the dust quantity, the duration of its presence, the dust's chemical composition and the plant species (Maletsika and Nanos, 2011). The particles matter accumulation on plant leaves may cause blocking of stomata and shading of photosynthetic tissue, and, as a result, reduction of leaf photosynthetic and transpiration capacity (Maletsika and Nanos, 2011).

Hirano, et al., (1995) reported that the effect of dusts deposited on cucumber and kidney bean plants was related to particle size: as the particle size decreased, it caused more shading to plant parts. The results of Grantz et al., (2003) indicated that increased particles matter dust deposition on vegetation may negatively affect carbon assimilation, due to shading and reduced stomatal conductivity.
Several Studies show that under polluted conditions, plants develop different morphological and anatomical changes (Inamdar and Chaudahri, 1984; Iqbal, 1985; Karenlampi, 1986; Gupta and Ghouse, 1988; Bhatti and Iqbal, 1988; Veselkin, 2004; Prajapati, 2012). The result of high dust deposition on the leaf surface in urban and industrial area have been reported by Tomašević and Aničić (2010) and Rahul and Jain (2014). They concluded that high dust deposition on leaf surface at road side with heavy vehicular traffic may be due to spray of unburnt oil residue of diesel or petrol on the leaf surface. Saravana and Sarala (2012) reported very high dust fall on the leaves of all plants under study growing in industrial in comparison to those growing in nonindustrial area.

\section{Conclusion}

1. As anatomical leaf properties under the industrial conditions, the results showed that the guard cells were more shrunken on the polluted leaves compared with unpolluted leaves in the 3 plant species.

2. Also, the particles were abundant and clumped together on the leaf surface of the plants growing in the industrial area.

3. The concentrations of $\mathrm{C}, \mathrm{O}, \mathrm{Mg}, \mathrm{Al}, \mathrm{Si}$ and $\mathrm{Ca}$ increased on the leaves collected from the polluted area as compared with unpolluted area.

4. $\mathrm{Na}, \mathrm{Pb}$ and $\mathrm{K}$ were found only on the surface of leaves collected from the polluted area.

\section{References}

Akguc, N., Ozyigit, I.I. and Yarci, C. (2008) Pyracantha coccinea Roem. (Rosaceae) as a biomonitor for $\mathrm{Cd}$, $\mathrm{Pb}$ and $\mathrm{Zn}$ in Mugla province (Turkey). Pak. J. Bot., 40 (4): 1767-1776.

Aksoy, A. and Demirezen, D. (2006) Fraxinus excelsior as a biomonitor of heavy metal pollution. Pol. J. Environ. Stud., 15 (1): 27-33.

Bhatnagar, V.S., Pawar, C.S., Jadhav, D.R. and Davies, J.C. (1985) Mermithid nematodes as parasites of 
Heliothis spp. and other crop pests in Andhara Pradesh, India. Proc. Indian Acad. Sci. 94: 509-515.

Bhatti, G.H. and Iqbal, M.Z. (1988) Investigations into the effect of automobile exhausts on the phenology, periodicity and productivity of some roadside trees. Acta Soc. Botanica. Poloniae, 57(3): 395-399.

Carpenter, K.J. (2005) Stomatal architecture and evolution in basal angiosperms. American Journal of Botany, 92: $1595-1615$.

Celik, A., Kartal, A.A., Akdogan, A. and Kaska, Y. (2005) Determining the heavy metal pollution in Denizli (Turkey) by using Robinio Pseudo-Acacia L. Environ. Int., 31: 105-112.

Christodoulakis, N.S. and Fasseas, C. (1990) Air pollution Effects on the Leaf Structure of Laurus nobilis, an Injury Resistant Species. Bulletin of Environmental Contamination and Toxicology. 44:276-281.

Dmuchowski, W. and Bytnerowicz, A. (2009) Long-term (1992-2004) record of lead, cadmium, and zinc air contamination in Warsaw, Poland: determination by chemical analysis of moss bags and leaves of Crimean linden. Environ Pollut. 157(12):3413-21.

Dykstra, M.J. (1993) A Manual of Applied Techniques for Biological Electron Microscopy. $2^{\text {nd }}$ printing. spiral bound.

Farmer, A.M. (1993) The effect of dust on vegetation - A review. Environ. Pollut. 79: 63-75.

Gautam, P., Blaha, U. and Appel, E. (2005) Magnetic susceptibility of dust-loaded leaves as a proxy of traffic related heavy metal pollution in Kathmandu City, Nepal. Atmos. Environ., 39: 2201-2211.

Gostin, I.N. (2009) Air pollution effects on the leaf structure of some Fabaceae species. Not. Bot. Hort. Agrobot. Cluj. 37(2): 57-63.

Grantz, D.A., Garner, J.H.B. and Johnson, D.W. (2003) Ecological effects of particulate matter. Environment International, 29: 213-239.

Gupta, M.C. and Ghouse, A.K.M. (1988) Effects of coal smoke pollutants from different sources in the growth, chlorophyll content, sten anatomy and cuticular traits of Euphorbia hirta L. Environmental Pollution, 47: 221-230.

Hayat, M.H. (2000). Biological Applications. $4^{\text {th }}$ edition. Cambridge Univ. Pr.

Hirano, T., Mitchison, T. J. and Swedlow, J. R. (1995) The SMC family: from chromosome condensation to dosage compensation. Curr. Opin. Cell Biol., 7: 329-336.

Inamdar, J.A. and Chaudahri, G.S. (1984) Effects of environmental pollutants of leaf epidermis and leaf architecture of Peristrophe bicalyculata. Journal of Plant Anatomy and Morphology, 1:1-8.

Iqbal, M., Abdin, M., Mahmooduzzafar, Z., Yunus, M. and Agrawal, M. (1996) Resistance mechanisms in plants against air pollution. In: Yunus, M., Iqbal, M. (Eds), Plant Response to Air Pollution. John Wiley, Chichester, pp: 194-240.

Iqbal, M.Z. (1985) Cuticular and anatomical studies of white clover leaves from clean and air-polluted areas. Pollution Research, 4: 59-61.

Iqbal, M.Z. and Shafig, M. (2001) Periodical effect of cement dust pollution on the growth of some plant species, Turk. J. Bot., 25: 19-24.
Karenlampi, L. (1986) Relationship between macroscopic symptoms of injury and cell structure changes in needle of ponderosa pine exposed to air pollution in California (USA). Annales Botanici Fennici, 23: 255-264.

Keskin, N. and Ili, P. (2012) Investigation of particular matters on the leaves of Pinus nigra ARN. Subsp. Pallasiana (Lamb.) Holmboein Denizli (Turkey). Pak. J. Bot., 44 (4): 1369-1374.

Lerman, S. (1972) Cement-kiln dust and the bean plant (Phaseolus vulgaris L. Black Valentine Var.); indepth investigations into plant morphology, physiology and pathology. Ph.D. Dissertation, University of California, Riverside.

Madejón, P., Marañón, T., Murillo, J.M. and Robinson, B. (2004) White Poplar (Populus alba) as a biomonitor of trace elements in contaminated Riparian Forests. Environ. Pollut., 132: 145-155.

Madejón, P., Marañón, T., Murillo, J.M. and Robinson, B. (2006) In defence of plants as biomonitors of soil quality. Environ. Pollut., 143: 1-3.

Maletsika, P.A. and Nanos, G.D. (2011) Effects of particulate matter contamination on apple, peach and olive tree leaf characteristics and olive leaf inorganic element composition. The annals of "Valahia" University of Targoviste, $5(\mathrm{~V}): 9-14$.

Maletsika, P.A. and Nanos, G.D. (2013) Effects of Particulate Matter Contamination on Peach Leaf Physiological Functions. Acta Hort. 981: 643-650.

Mingorance, M.D. and Oliva, S.R. (2006) Heavy metals content in $N$. oleander leaves as urban pollution assessment. Environ. Monit. Assess., 119: 57-68.

Pal, A., Kulshshreshtha, K., Ahmad, K.J. and Bhel, H.M. (2002) Do leaf surface characters play a role in plant resistance to auto exhaust pollution? Flora, 197: $47-55$.

Prajapati, S.K. (2012) Ecological effect of airborne particulate matter on plants. Environmental Skeptics and Critics, 1(1):12-22.

Prajapati, S.K. and Tripathi, B.D. (2008) Seasonal Variation of leaf dust accumulation and pigment content in plant species exposed to urban particulates pollution. Journal of Environment Quality. 37: 865-870.

Rahul, J. and Jain, M.K. (2014) An Investigation in to the Impact of Particulate Matter on Vegetation along the National Highway: A Review. Research Journal of Environmental Sciences, 8: 356-372.

Rao, D. N. and Pal, D. (1979) The effects of fluouride pollution on the organic matter content of soil. Plant and Soil, 49: 653-656.

Saadullah, K.L., Asrar Zaidi, M., Sarangzai, A.M., Faheem, M., Shawani, G.R. and Ali, W. (2014) Effect of road side dust pollution on the growth and total chlorophyll contents in Vitis vinifera L. (grape). Afr. J. Agric. Res., 13 (11): 1237-1242.

Saquib, M. Ahmad, A. and Ansari, K. (2010) Morphological and Physiological Responses of Croton Bonplandianum Baill. to air Pollution. ECOPRINT 17: $35-41$.

Saravana, K.R. and Sarala, T.D. (2012) Effect of cement dust deposition on physiological behaviors of some selected plant species. International J. of Scientific \& Technology research, 1 (9): 98-105. 
Shetye, R. P. and Chaphekar, S. B. (1980) Some estimations on dust fall in the city of Bombay, using plants. Vol. 4: pp. 61-70. In: Progress in Ecology. V. P. Agarwal and V.K. Sharma (Eds.). Today and Tomorrow's Printers and publishers, New Delhi.

Tomašević, M. and Aničić, M. (2010) Trace element content in urban tree leaves and SEM-EDAX characterization of deposited particles, Facta Universitatis Series: Physics, Chemistry and Technology, 8 (1): 1-13.

Tomasevic, M.S., Rajsic, D., Dordevic, M., Tasic, J., Krstic, A. and Novakovic, V. (2004) Heavy metals accumulation in tree leaves from urban areas. Environ. Chem. Lett., 2 (3): 151-154.

Veselkin, D. V. (2004) Anatomical Structure of Ectomycorrhiza in Abies sibirica Ledeb. and Picea obovata Ledeb. under Conditions of Forest Ecosystems Polluted with Emissions from Copper-
Smelting Works. Russian Journal of Ecology, 35: 71.

Wang, L., Gong, H, Liao, W. and Wang, Z. (2015) Accumulation of particles on the surface of leaves during leaf expansion. Science of The Total Environment, 532:420-434.

Yilmaz, R., Sakcali, S., Yarci, C., Aksoy, A. and Ozturk, M. (2006) Use of Aesculus hippocastanum L. as a biomonitor of heavy metal pollution. Pak. J. Bot., 38(5): 1519-1527.

Youssef, N.A., Gurbanov, E.M., Haciyeva, S.R., Mammedova, A.O. and Khalilov, R.I. (2013) Antioxidant Enzymes, Fluctuating Asymmetry and Morphological Changes of Urban Trees as an Ecological Indicators of Heavy Metal Stress. International Journal of Pharmaceutical Science and Health Care, 3 (1): 1-18. 


\section{تراكم الجسيمات والصفات التشريحية لأوراق ثناثة أنواع من الأثجار تتموا في المنطقة الصناعية بجدة، المملكة العربية السعودية}

شاهين، أحمد محمد عبدالرحيم؛ والطوخي، عبدالمنعم عبدالمجيد؛ وآل حجر، عبدالرحمن سعيد

قسم علوم الأحباء، كلية العلوم، جامعة الملك عبدالعزبز، جدة، المدلكة العربية السعودية

Cinnamomum (المستخلص. تم دراسة نراكم الجسيمات والخصائص التشريحية للأوراق أشجار الكافور (Bom (Camphora

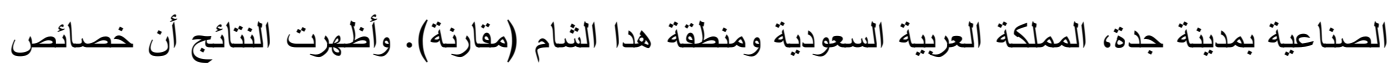
الورقة وجميع أنواع الأثجار التي تتمو في المنطقة الصناعية ومنطقة المقارنة أن كل ثخر لله حافة مرتفعة الهنة على منطقة الخلية الحارسة. كما ظهرت الخلايا الحارسة منكمشة أكثر على الأوراق الملوثة مقارنة بالأوراق غير الملوث. وأثنارت النتائج إلى أن معظم الجسيمات المترسبة على سطوح الأوراق في جميع أنواع الأشجار هي: السخام (الكربون) وغبار التربة المحتوي على عناصر (السليكون، والألومنيوم، والمغنيسيوم، الألى

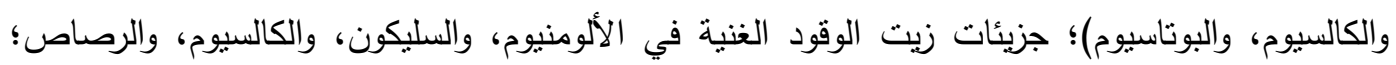

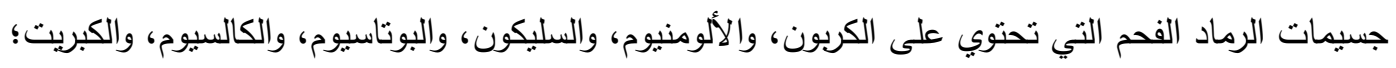
والرصاص. وبناءً على ذلك، يمكن استخدام أوراق تلك الأنواع النباتية كمؤشرات حيوية لتقييم الجسيمات في ولي ولئي المناطق الصناعية. 